\title{
Carnosine and Related Compounds Protect against the Hydrogen Peroxide-Mediated Cytochrome $c$ Modification
}

\author{
Jung Hoon Kang \\ Department of Genetic Engineering, Cheongju University, Cheongju 360-764, Korea. E-mail: jhkang@cju.ac.kr
} Received January 10, 2006

\begin{abstract}
Carnosine, homocarnosine and anserine might act as anti-oxidants and free radical scavengers in vivo. In the present study, the protective effects of carnosine and related compounds on the $\mathrm{H}_{2} \mathrm{O}_{2}$-mediated cytochrome $c$ modification were studied. Carnosine, homocarnosine and anserine significantly inhibited the oligomerization of cytchrome $c$ induced by $\mathrm{H}_{2} \mathrm{O}_{2}$. All three compounds also inhibited the formation of carbonyl compound and dityrosine during the incubation of cytochrome $c$ with $\mathrm{H}_{2} \mathrm{O}_{2}$. These compounds effectively inhibited the peroxidase activity in the cytchrome $c$ treated with $\mathrm{H}_{2} \mathrm{O}_{2}$. The results suggested that carnosine, homocarnosine, and anserine might protect cytochrome $c$ against $\mathrm{H}_{2} \mathrm{O}_{2}$-mediated oxidative damage through a free radical scavenging.
\end{abstract}

Key Words : Cytochrome $c$, Oligomerization, Free radical scavenger, Carnosine

\section{Introduction}

Histidine dipeptides, carnosine ( $\beta$-alanyl-L-histidine), homocarnosine ( $\gamma$-amino-butyryl-L-histidine) and anserine $(\beta$ alanyl-1-methyl-L-histidine) are present in the muscle and brain tissues of human and other vertebrates in relatively high concentrations (1-20 mM). ${ }^{1,2}$ Although their physiological roles have not been fully established, these compounds have been postulated to have numerous biological functions including $\mathrm{pH}$ buffering, regulation of enzyme activity, and inhibition of oxidative reactions. It has been reported that carnosine and related peptides are able to inactivate reactive oxygen species (ROS), scavenge free radicals, and chelate prooxidant metals. ${ }^{3-6}$ Because of the interesting biological activities of carnosine, some potential medical uses of these peptides have been suggested such as in the treatment of gastric ulcers, arthritis, inflammation, and diseases caused by active oxygen. ${ }^{7}$

Cytochrome $c$ is well known as the penultimate electron transport protein of the eukaryotic respiratory chain. ${ }^{8}$ However, recent discoveries implicate this protein has two other biological processes, apoptosis and oxidative stress. ${ }^{9,10}$ Apoptosis, also called programmed cell death, is key to development and is linked to human diseases, including cancer and neurodegeneration. ${ }^{11,12}$ The cellular damage associated with oxidative stress has also been associated with several diseases, such as Parkinson's disease (PD). Specially, it has been shown that cytochrome $c$ is colocalized with $\alpha$-synuclein aggregates in Lewy bodies which are the pathological hallmarks of $\mathrm{PD}^{13}$ and that cytochrome $c$ catalyzes the $\mathrm{H}_{2} \mathrm{O}_{2}$-induced aggregation of $\alpha$-synuclein. ${ }^{10}$

In addition to the function of electron transfer, cytochrome $c$ catalyzes peroxidase-like reaction in vitro. ${ }^{14-16}$ It catalyses several reactions such as hydroxylation and aromatic oxidation and shows peroxidase activity by oxidation of various electron donors such as 2-keto-4-thiomethyl butyric acid, and 4-aminoantipyrine. Recently, it was reported that hydrogen peroxide oxidized cytchrome $c$ to a peroxidase compound I-type intermediate, in which one oxidizing equivalent is present as an oxoferryl heme species and the other is present as the protein tyrosyl radical. ${ }^{17}$

Oxidative modification of proteins implicated in the development of many human diseases and aging. ${ }^{18,19}$ The damage that oxidative stress causes to proteins includes side chain modification and main chain fragmentation. Two biological markers for oxidative damage in proteins are the accumulation of carbonyl compounds and the accumulation of dityrosine. ${ }^{19}$ Such an oxidative modification is an indicator of oxidative stress and may be significant in several physiological and pathological processes. ${ }^{20,21}$ Carnosine and related compounds prevents protein modification by scavenging free radicals, ${ }^{22}$ lipid perodative products, ${ }^{23}$ and carbohydrate oxidation products. $^{24}$ Since the oxidative modification of cytochrome $c$ is associated with neurodegenerative disorders, protective effects of carnosine and related compounds, in part, may provide a potential therapeutic method for pathogenesis that involve the oxidative damage of protein mediated by ROS. Although much has been written on anti-oxidant and free radical scavenging activities of carnosine and related compounds, the protective effects of these compounds on the modification of cytochrome $c$ by oxidative stress have not been reported. In the present study, the protective effects of carnosine and related compounds on the modification of cytochrome $c$ induced by $\mathrm{H}_{2} \mathrm{O}_{2}$ were investigated. Carnosine, homocarnosine and anserine effectively inhibited the oligomerization of cytochrome $c$ induced by $\mathrm{H}_{2} \mathrm{O}_{2}$. In addition, it was found that carnosine and related compounds inhibited the formation of carbonyl compounds and dityrosine in the protein which had been treated with $\mathrm{H}_{2} \mathrm{O}_{2}$.

\section{Materials and Methods}

Materials. Bovine cytochrome $c$, dinitrophenyl amine, 
carnosine, homocarnosine and anserine were purchased from Sigma. Acrylamide, sodium dodecyl sulfate (SDS) and Chelex 100 resin (sodium form) was obtained from BioRad. All materials were treated with Chelex 100 resin.

Analysis of cytochrome $c$ oligomerization by $\mathbf{H}_{2} \mathbf{O}_{2} .100$ $\mu \mathrm{M}$ Cytochrome $c$ was incubated with $1 \mathrm{mM} \mathrm{H} \mathrm{H}_{2}$ in 10 $\mathrm{mM}$ potassium phosphate buffer $\left(\mathrm{pH} \mathrm{7.4)}\right.$ ) at $37{ }^{\circ} \mathrm{C}$ for $2 \mathrm{~h}$. After stopping the reaction by adding catalase to a final concentration of $100 \mu \mathrm{g} / \mathrm{mL}$, aliquots were diluted $4 \times$ concentrated sample buffer $(0.25 \mathrm{mM}$ Tris- $\mathrm{HCl}, 8 \%$ SDS, $40 \%$ glycerol, $20 \% \beta$-mercaptoethanol, $0.01 \%$ bromophenol blue) and were boiled at $100{ }^{\circ} \mathrm{C}$ for $10 \mathrm{~min}$ before electrophoresis. An aliquot of each sample was subjected to SDSpolyacrylamide gel electrophoresis (PAGE) as described Laemmli ${ }^{25}$ by using a slab gel (stacking gel, $2.5 \%$ acrylamide, and separating gel, 18\% acrylamide). For immunoblotting, the proteins on the polyacrylamide gel were electrophoretically transferred to nitocellulose membrane which was, in turn, blocked in 5\% nonfat milk in Tris-buffered saline (TBS: $20 \mathrm{mM}$ Tris, $0.2 \mathrm{M} \mathrm{NaCl}, \mathrm{pH} 7.5)$ containing $0.05 \%$ tween-20 (TTBS). The membrane was incubated for $1 \mathrm{~h}$ at room temperature with anti-cytochrome $c$ antibody (1 : 400) in TTBS. The membrane was washed by TTBS and incubated again with peroxidase labeled secondary antibody. The protein bands were visualized with enhanced chemiluminescence kit (PerkinElmer).

Preparation of anti-cytochrome $c$ antibody. The purified cytochrome $c$ was mixed with an equal volume of complete Freund's adjuvant and was injected into a rat. Two booster injections with incomplete Freund's adjuvant at three-week intervals were followed by a final injection. Two weeks after a final injection, the rat was bled and the antiserum collected.

Detection of protein carbonyl compound. The carbonyl content of proteins was determined by immunoblotting with anti-DNP antibody as described elsewhere. ${ }^{26}$ Both native and oxidized proteins were incubated with $20 \mathrm{mM}$ DNPH in $10 \%(\mathrm{v} / \mathrm{v})$ trifluoroacetic acid at room temperature for $1 \mathrm{~h}$. After incubation, a neutralization solution (2 M Tris) was added at room temperature for $15 \mathrm{~min}$. After SDS-PAGE of the derivatized protein with $18 \%$ polyacrylamide gel, the proteins were transferred onto a nitrocellulose sheet and then probed with rabbit anti-DNP sera, used a dilution of 1 : 1000. The detection method used alkaline phosphataselabelled goat anti rabbit IgG with the BCIP/NBT detecting system (Bio-Rad).

Measurement of peroxidase activity of cytochrome $c$. The peroxidase activity of cytochrome $c$ was measured by using a chromogen, 2,2'-azinobis-(2-ethylbenzthiazoline-6sulfonate) (ABTS). ${ }^{27}$ ABTS is water-soluble and has a strong absorption at $340 \mathrm{~nm}$ with a molar extinction coefficient $\varepsilon_{340}$ of $3.66 \times 10^{4} \mathrm{M}^{-1} \mathrm{~cm}^{-1}{ }^{28}$ On oxidation, ABTS forms a stable blue-green product presumed to be the cation radical, $\mathrm{ABTS}^{+} \cdot$ is conveniently followed at $\lambda_{\max }$ at $415 \mathrm{~nm}$ $\left(\varepsilon_{415}=3.6 \times 10^{4} \mathrm{M}^{-1} \mathrm{~cm}^{-1}\right) \cdot{ }^{29}$ The assay mixture contained 10 $\mathrm{mM}$ potassium phosphate buffer $(\mathrm{pH} 7.4)$ and $50 \mu \mathrm{M}$ ABTS and $0.3 \mathrm{mM}$ hydrogen peroxide and $5 \mu \mathrm{M}$ protein in a total volume of $1 \mathrm{~mL}$. The reaction was initiated by addition of hydrogen peroxide and the increase in absorbance at $415 \mathrm{~nm}$ was measured by using a UV/Vis spectrophotometer (Shimazu 1601).

\section{Results and Discussion}

When cytochrome $c$ was incubated with $1 \mathrm{mM} \mathrm{H}_{2} \mathrm{O}_{2}$, the protein oligomerization occurred (Fig. 1A, B and C, lane 2). Effects of carnosine, homocarnosine and anserine on the oligomerization of cytochrome $c$ by $\mathrm{H}_{2} \mathrm{O}_{2}$ was investigated. These compounds showed a concentration-dependent inhibition of the cytochrome $c$ oligomerization induced by $\mathrm{H}_{2} \mathrm{O}_{2}$ (Fig. 1A, B and C). It has been shown that protein oxidation is accompanied the conversion of some amino acid residues into carbonyl derivatives. ${ }^{26}$ The carbonyl content of protein can be measured using phenylhydrazine formation reaction. The method for detecting carbonyl-containing proteins employs derivatization with 2,4-DNPH followed by analysis with anti-DNP sera in a immunoblotting procedure. ${ }^{30}$ Results obtained from the immunoblotting analysis of $\mathrm{H}_{2} \mathrm{O}_{2}$ treated cytochrome $c$ are shown in Figure 2. The incubation of cytochrome $c$ with $1 \mathrm{mM} \mathrm{H}_{2} \mathrm{O}_{2}$ resulted in the formation of carbonyl compounds (Fig. 2A, B and C, lane 2). Carnosine, homocarnosine and anserine protect the formation of
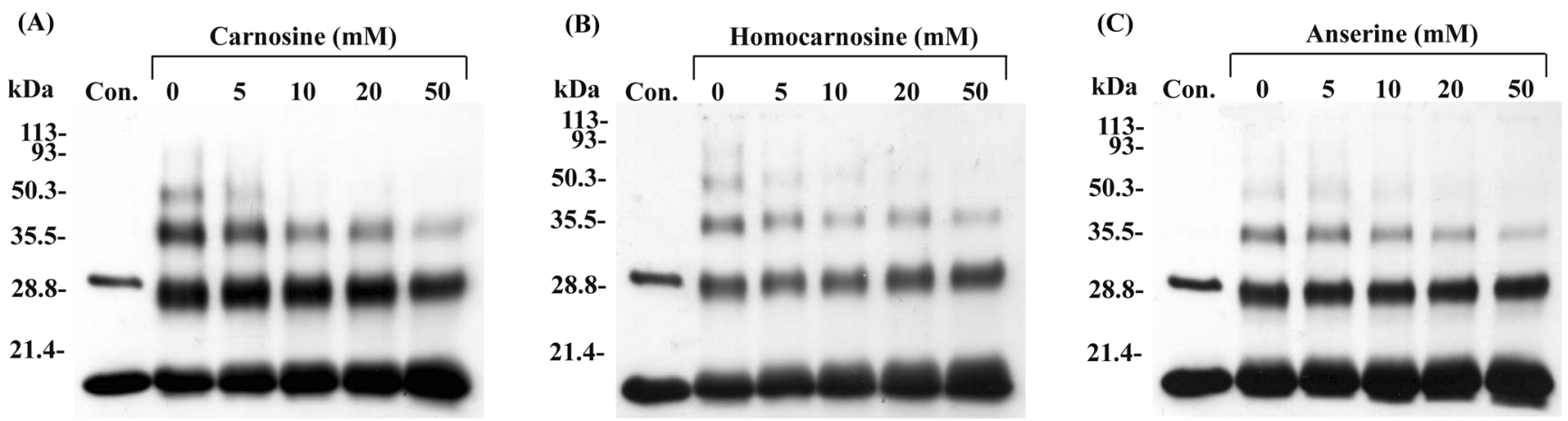

Figure 1. Effects of carnosine, homocarnosine and anserine on the oligomerization of cytochrome $c$ by $\mathrm{H}_{2} \mathrm{O}_{2}$. Cytochrome $c$ was incubated with $1 \mathrm{mM} \mathrm{H}_{2} \mathrm{O}_{2}$ in various concentration of carnosine (A) homocarnosine (B) and anserine (C) at $37{ }^{\circ} \mathrm{C}$ for $2 \mathrm{~h}$. Lane 1 , cytochrome $c$ control; lane 2, incubated with $\mathrm{H}_{2} \mathrm{O}_{2}$; lane 3,5 mM effectors; lane 4, $10 \mathrm{mM}$ effectors; lane 5, $20 \mathrm{mM}$ effectors; lane 6, $50 \mathrm{mM}$ effectors. Analysis of protein oligomerization was performed by immunoblotting. 
(A)

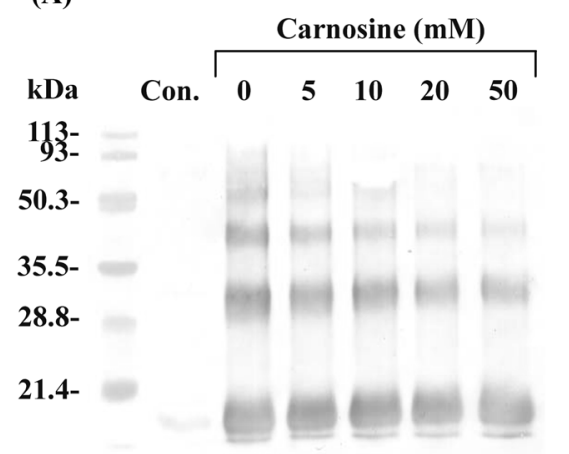

(B)

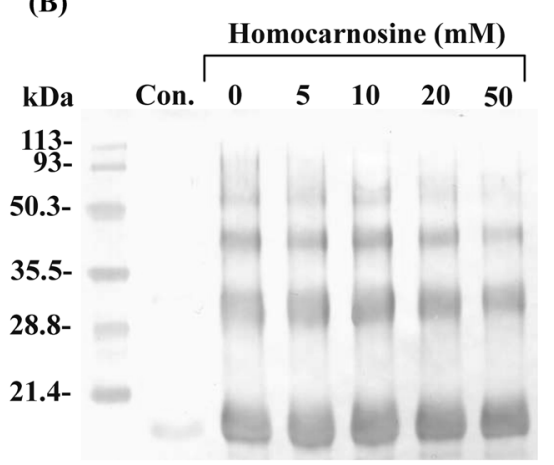

(C)

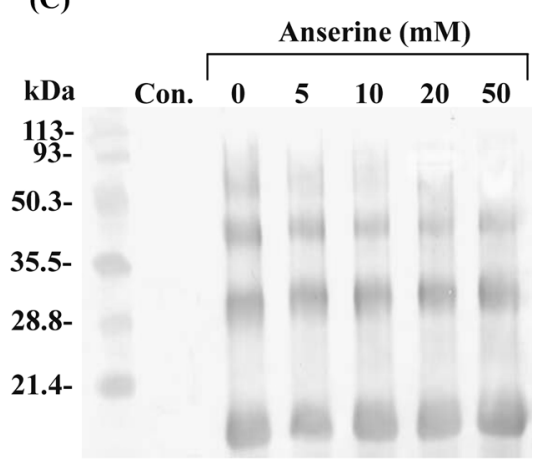

Figure 2. Effects of carnosine, homocarnosine and anserine on the formation of carbonyl compounds in the cytochrome $c$ and $\mathrm{H}_{2} \mathrm{O}_{2}$ system. Cytochrome $c$ was incubated with $1 \mathrm{mM} \mathrm{H}_{2} \mathrm{O}_{2}$ in various concentration of carnosine (A) homocarnosine (B) and anserine (C) at $37^{\circ} \mathrm{C}$ for 2 h. Lane 1, cytochrome $c$ control; lane 2, incubated with $\mathrm{H}_{2} \mathrm{O}_{2}$; lane 3, $5 \mathrm{mM}$ effectors; lane $4,10 \mathrm{mM}$ effectors; lane 5, $20 \mathrm{mM}$ effectors; lane 6, $50 \mathrm{mM}$ effectors. Analysis of carbonyl compounds was performed by using anti-DNP antibody.

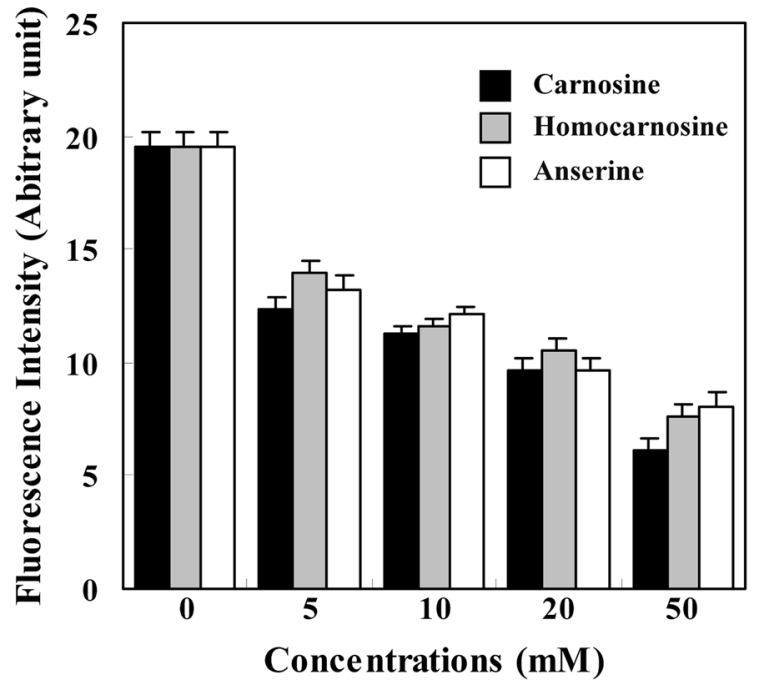

Figure 3. Effects of carnosine and related compound on the formation of dityrosine in $\mathrm{H}_{2} \mathrm{O}_{2}$-mediated cytochrome $c$ modification. $100 \mu \mathrm{M}$ cytochome $c$ was incubated with $1 \mathrm{mM}$ $\mathrm{H}_{2} \mathrm{O}_{2}$ in various concentration of carnosine and related compound at $37^{\circ} \mathrm{C}$ for $2 \mathrm{~h}$. Reactions were stopped by adding catalase to a final concentration of $100 \mu \mathrm{g} / \mathrm{mL}$ and an aliquot was analyzed by fluorescent spectrometer. Data represent the means S.D. $(n=3-5)$. carbonyl compounds (Fig. 2A, B and C). Since carnosine and related compounds are good scavengers of free radicals, the prevention of protein carbonyl formation may be due to the free radical-scavenging activity of these compounds. However, carnosine can react non-enzymatically with carbonyl groups on proteins, a process termed "carnosylation". ${ }^{31}$ Both prevention and removal of protein carbonyl may act an important role in the protection of cytochrome $c$ against oxidative stress. It has been reported that $o, o^{\prime}$-dityrosine crosslink formation between dityrosine residues may play a part in the formation of oxidative covalent protein crosslink. ${ }^{19}$ The effects of carnosine and related compounds on the formation of $o, o^{\prime}$-dityrosine during the incubation of cytochrome $c$ with $\mathrm{H}_{2} \mathrm{O}_{2}$ were investigated by measuring fluorescence emission spectrum between 340 and $500 \mathrm{~nm}$ with an excitation at $325 \mathrm{~nm}$. The incubation of cytochrome $c$ with $1 \mathrm{mM} \mathrm{H}_{2} \mathrm{O}_{2}$ led to the formation of $o, o^{\prime}$-dityrosine crosslinks whereas carnosine, homocarnosine and anserine inhibited the formation of $o, o^{\prime}$-dityrosine (Fig. 3 ).

The damage that oxidative stress causes to proteins includes side chain modification and main chain fragmentation. Two biological markers for oxidative damage in proteins are the accumulation of carbonyl compounds and the accumulation
(A) Carnosine

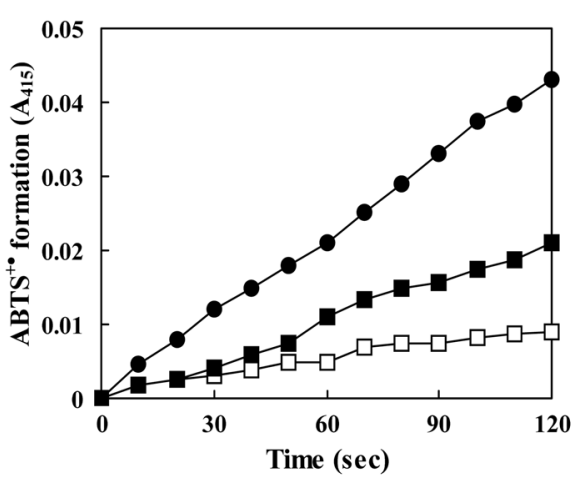

(B) Homocarnosine

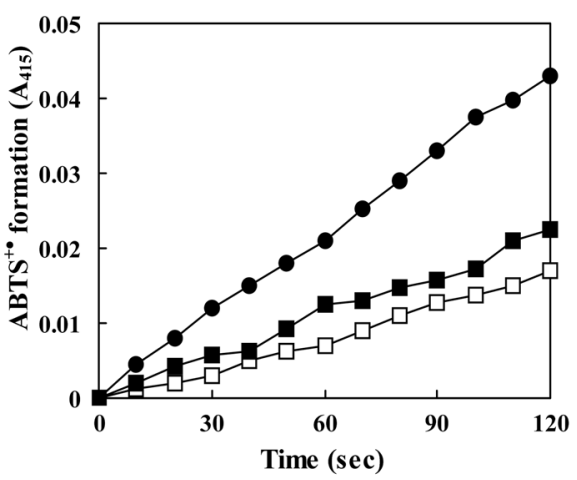

(C) Anserine

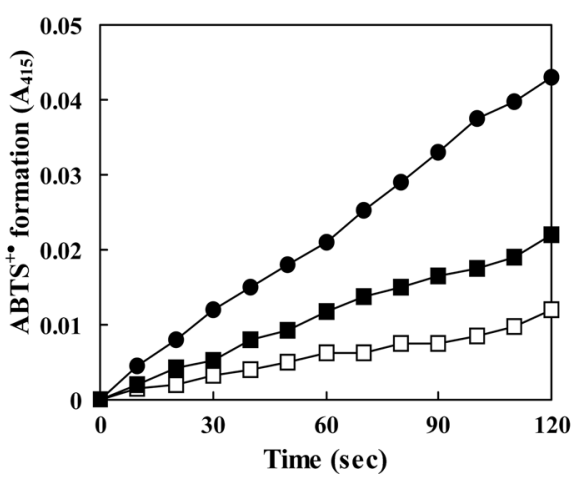

Figure 4. Effects of carnosine, homocarnosine and anserine on the formation of $\mathrm{ABTS}^{+\bullet}$ by the reaction of cytochrome $c$ with $\mathrm{H}_{2} \mathrm{O}_{2}$. The reaction mixture was contained $50 \mu \mathrm{M}$ ABTS, $5 \mu \mathrm{M}$ cytochrome $c, 0.3 \mathrm{mM} \mathrm{H}_{2} \mathrm{O}_{2}$ in $10 \mathrm{mM}$ potassium phosphate buffer (pH 7.4), in absence of effector $(\bullet)$, in presence $0.1 \mathrm{mM}(\square), 1 \mathrm{mM}(\square)$ effectors. The absorbance was monitored at $415 \mathrm{~nm}$ for $2 \mathrm{~min}$. 
of dityrosine. ${ }^{19}$ It has been reported that $\cdot \mathrm{OH}$ might play a role in the formation of carbonyl compounds and dityrosine. ${ }^{32}$ Therefore, the present results suggested that carnosine and related compounds inhibited the formation of carbonyl compounds and dityrosine in the modified cytochrome $c$ through a mechanism of free radical scavenging. The reaction of $\mathrm{ABTS}$ with $\cdot \mathrm{OH}$ forms a stable blue-green product presumed to be the cation radical, $\mathrm{ABTS}^{+}$. This reaction can be used to detect $\cdot \mathrm{OH}$ production, although it is unclear whether or not some other reactive oxygen species can also react with ABTS. When cytochrome $c$ was incubated with $\mathrm{H}_{2} \mathrm{O}_{2}$ in the presence of carnosine, homocarnosine and anserine at $37^{\circ} \mathrm{C}$, all compounds significantly inhibited the peroxidase activity of cytochrome $c$ (Fig. 4). It has been reported that iron ions might play a role in the peroxidase activity of cytochrome $c .{ }^{16}$ Carnosine and related compounds have not been found to chelate iron in a manner that reduces its prooxidant activity. ${ }^{1}$ It has been reported that carnosine and related compounds quench $50-95 \%$ of hydroxyl radicals produced in the Fenton reaction. ${ }^{33}$ Thus it can be assumed that the ability of carnosine and related compounds to inhibit $\mathrm{H}_{2} \mathrm{O}_{2}$-mediated cytochrome $c$ modification was likely due to free radical scavenging activity.

The modification of cytochrome $c$, in part, may be responsible for the deleterious effects observed by mitochondria dysfunction. Therefore, it was suggested that carnosine and related compounds might protect cells from the deleterious effects by $\mathrm{H}_{2} \mathrm{O}_{2}$-mediated cytochrome $c$ modification.

\section{References}

1. Kohen, R.; Yamamoto, Y.; Cundy, K. C.; Ames, B. N. Proc. Natl. Acad. Sci. U. S. A. 1988, 85, 3175.

2. O’Dowd, J. J.; Robins, D. J.; Miller, D. J. Biochem. Biophys. Acta 1988, 967, 241.

3. Boldyrev, A. A.; Dupin, A. M.; Pindel, E. V.; Severin, S. E. Comp. Biochem. Physiol. 1988, 89B, 245.

4. Auroma, O. I.; Laughton, M. J.; Halliwell, B. Biochem. J. 1989, 264, 863.

5. Brown, C. E. J. Theor. Biol. 1981, 88, 296.

6. Decker, E. A.; Crum, A. D.; Calvert, J. T. J. Agric. Food Chem.
1992, 40, 756

7. Nagai, K.; Suda, T.; Kawasaki, K.; Mathuura, S. Surgery 1986 , $100,815$.

8. Moore, G. R.; Pettigrew, G. W. Cytochrome c: Evolution, Structure, and Physicochemical Aspects; Springer-Verlag: Berlin, 1990.

9. Li, P.; Nijhawan, D.; Budihardjo, I.; Srinvasula, S. M.; Ahmad, M.; Alnermri, E. S.; Wang, X. Cell 1997, 91, 627.

10. Hashimoto, M.; Takeda, A.; Hsu, L. J.; Takenouchi, T.; Masliah, E. J. Biol. Chem. 1999, 274, 28849.

11. Green, D. R.; Evan, G. I. Cancer Cell 2002, 1, 19.

12. Shimizu, S.; Narita, N.; Tsujimoto, Y. Nature 1999, 399, 483.

13. Wang, X.; Pielak, G. J. Biochemistry 1999, 38, 16876.

14. Radi, R.; Thomson, L.; Rubbo, H.; Prodanov, E. Arch. Biochem. Biophys. 1991, 288, 112.

15. Vazquez-Duhalt, R. J. Mol. Catal. B. Enzym. 1999, 7, 241

16. Kim, N. H.; Jeong, M. S.; Choi, S. Y.; Knag, J. H. Bull. Korean Chem. Soc. 2004, 25, 1889.

17. Lawrence, A.; Jones, C. M.; Wardman, P.; Burkitt, M. J. J. Biol. Chem. 2003, 278, 29410.

18. Halliwell, B.; Gutteridge, J. M. C. Mol. Aspects Med. 1985, 8, 89

19. Berlett, B. S.; Stadtman, E. R. J. Biol. Chem. 1997, 272, 20313.

20. Davies, K. J. J. Free Radic. Biol. Med. 1986, 2, 155.

21. Oliver, C. N.; Levine, R. L.; Stadtman, E. R. J. Am. Geriatr. Soc. 1987, 35, 947

22. Klebanov, G. I.; Teselkin, Yu. O.; Babenkova, J. V.; Popov, I. N.; Levin, G.; Tyulina, O. V.; Boldyrev, A. A.; Vladimirov, Yu. A. Biochem. Mol. Biol. Int. 1997, 43, 99.

23. Hipkiss, A. R.; Worthington, V. C.; Himsworth, D. T.; Herwig, W. Biochim. Biophys. Acta 1998, 1380, 46.

24. Seidler, N. W.; Yeargans, G. S. Life Sci. 2002, 70, 1789.

25. Laemmli, U. K. Nature 1970, 27, 680.

26. Levine, R. L.; Williams, J. A.; Stadtman, E. R.; Shacter, E. Methods Enzymol. 1994, 233, 346.

27. Thomson, R.; Rubbo, L.; Prodanov, E. Arch. Biochem. Biophys. 1991, 288, 112 .

28. Rush, J. D.; Koppenol, W. H. J. Am. Chem. Soc. 1988, 110, 4957.

29. Childs, R. E.; Bardsley, W. G. Biochem. J. 1975, 145, 93.

30. Towbin, H.; Staehelin, T.; Gordon, J. Proc. Natl. Acad. Sci. U.S.A. 1979, 76, 4350.

31. Hipkiss, A. R.; Brownson, C.; Carrier, M. J. Mech. Aging Devel. 2001, 122, 1431.

32. Halliwell, B.; Gutteridge, J. M. C. Free Radicals in Biology and Medicine; Oxford: New York, 1999.

33. Chan, W. K. M.; Decker, E. A.; Lee, J. B.; Butterfield, D. A. J. Agric. Food Chem. 1994, 42, 1407. 